\title{
Management of Hyperlipidaemia through Ayurvedic Intervention
}

\author{
Jaya Saklani Kala and Swapnil Singhai
}

\section{ABSTRACT}

\begin{abstract}
The potential of hyperlipidemia to engage in the pathology of atherosclerotic diseases such as coronary heart disease, which dominates the scenario of diseases causing morbidity and mortality in the world. Hyperlipidemia is defined as elevated serum levels of cholesterol, triglycerides, or both. It is characterized by abnormally elevated lipid concentrations in blood caused by impaired lipid and lipoprotein metabolism and has the potential to cause a variety of complications such as cardiovascular disease, diabetes, obesity, hypertension, atherosclerosis, and so on. Hyperlipidemia is classified as Medoroga in Ayurveda. The results obtained for the lipid profile parameter demonstrated a significant change. The difference in total serum cholesterol is $36 \mathrm{mg} / \mathrm{dl}$, serum triglycerides is $32 \mathrm{mg} / \mathrm{dl}$, serum LDL is $40 \mathrm{mg} / \mathrm{dl}$, serum VLDL is $15 \mathrm{mg} / \mathrm{dl}$ and serum HDL is $-3 \mathrm{mg} / \mathrm{dl}$.
\end{abstract}

Keywords: Hyperlipidemia, Dyslipidemia, Medoroga, Medoharvidangadi Loha.
Submitted : April 15, 2021

Published : May 06, 2021

ISSN: $2593-8339$

DOI: $10.24018 /$ ejmed.2021.3.3.815

\section{Jaya Saklani Kala*}

Uttarakhand Ayurved University, Rishikul Campus, Haridwar, Inida. Swapnil Singhai

Principal cum M. S, Poornayu Ayurved Hospital, Jabalpur, M.P. India.

(e-mail: ditiayurveda@ ${ }^{\circledR}$ gmail.com)

\section{INTRODUCTION}

Lipids are non-polar hydrophobic molecules that are needed by all living cells. They serve many important roles in the human body, including playing an important role in cellular structure, acting as concentrated sources of energy storage, metabolic regulators, shielding internal organs via a cushioning effect, and so on. Both of these lipids are known as depot lipids because they are retained in the body, while others circulate in the blood.

Hyperlipidemia is one such dietary condition that has been described as a possible risk factor for a wide range of diseases including cardiovascular disease, metabolic syndrome, and even hypertension. The ability of hyperlipidemia to engage in the pathology of atherosclerotic diseases such as coronary heart disease, which dominates the scenario of diseases causing morbidity and mortality in the region, has piqued the interest of researchers worldwide. Hyperlipidemia is described as elevated serum levels of cholesterol, triglycerides, or both.

While there is no specific terminology for hyperlipidemia in the Ayurvedic classics, Rasagata Sneha Vriddhi, Rasa Raktagata Sneha Vriddhi, Medovriddhi, Medoroga or Medodosha, Ama Medo Dhatu use for the same. On the basis of its pathophysiology, hyperlipidemia is identical to Asthayi Medo Dhatu Vriddhi. Furthermore, since this unnecessarily elevated Asthayi Medo Dhatu is Ama in origin, it is stored in the body for a longer period of time, resulting in additional complications. The affected Kapha Dosha and Medo Dhatu are also found to play a key role in the pathogenesis of Atisthaulya and Prameha in Hyperlipidemia.
Medoroga is a condition caused by an irregular accumulation of medodhatu. It is caused by vitiated Kapha dosha at first, and then Pitta and Vata dosha play a part in its pathogenesis, causing symptoms of their own. In later stages, pathological accumulations of abhaddha apachita medas in other srotus cause various symptoms such as Javoparodha, Ayushohrasa, Swedhsbhaada, and so on. Avyayama, Adhyashana, Divasvapna, Ati madhura, Guru, Snigdha Ahara sevana, multiple Manasika Bhavas, and Beejadosha are some of the nidanas that patients do. The appearance of symptoms such as Swedadhikya, Atikshudha, Atipipasa, Daurgandhya, Daurbalya, Utsahahani, and others indicates the involvement of other doshas such as Pitta and Vata.

Aptarpana Chikitsa can be used with measures such as Ullekhana, Raktamokshana, Vyayama, Upavasa, Dhuma, Swedana, Sakshaudra Ahara, Abhayaprasha, Rukshanna Sevana, and various forms of Churnas and Pradehas. Since Kapha Dosha and Medo Dhatu are the primary vitiated factors in the pathogenesis of Hyperlipidemia, Vishesha Chikitsa refers to the test that leads to a decrease in the former two. Since the treatment of two diseases, Sthaulya and Prameha, aims to reduce unnecessary Kapha Dosha and Medo Dhatu, these can also be seen as a treatment option for the Vriddha Asthayi Medo Dhatu.

Acharya Sushruta stated Shilajatu, Guggulu, Gomutra, Triphala, Loharaja, Rasanjana, Madhu, Yava, Kordusha, Shyamaka, Uddalaka, Virukshana and Chedaniya Dravyas, Vyayama and Lekhana Basti in Sthaulya chikitsa. Acharya listed various tasks, based on the patient's needs, for inducing optimum physical effort, such as workouts, chariot travel, and long-distance walking. Also recommended walking a distance of 100 Yojana and adhering to dietary restrictions. 
Major risk factors (Exclusive of LDL Cholesterol):

- Smoking cigarettes;

- Hypertension (blood pressure above 140/90 mmHg or use of antihypertensive medication);

- Low HDL cholesterol (40 mg/dl);

- Premature CHD in the family (CHD in male first degree relative 55 years; $\mathrm{CHD}$ in female first degree relative 65 years);

- The age (men 45 years; women 55 years).

Initiate therapeutic lifestyle changes if LDL is above goal:

- Therapeutic dietary and lifestyle Diet plan;

- Consider increasing viscous (soluble) fiber (10$25 \mathrm{~g} /$ day) and plant stanols/sterols (2 g/day) as therapeutic alternatives to boost LDL lowering;

- Weight loss;

- Increased physical exercise.

In 2000 the AHA revised its guidelines, which place emphasis on foods rather than nutrients and added weight management as a goal. The AHA guidelines include:

- $30 \%$ of calories come from overall fat consumption.

- $10 \%$ of calories should come from saturated fat.

- $300 \mathrm{mg}$ of dietary cholesterol per day

- Two servings of cold-water fish rich in omega-3 fatty acids per week.

- Eat more fruits and vegetables, as well as low-fat and fat-free dairy products.

- Replace saturated fat with whole grains, fruits, fish, legumes, and nuts.

- Limit the salt intake to 6 grams a day.

- Limit alcohol consumption to two drinks a day for men and one drink a day for women.

- Keep a balanced body weight.

- Increase your physical exercise level.

Total Cholesterol Level:

- Desirable - <200 mg/dl;

- Borderline high - 200-239 mg/dl;

- High $-\geq 240 \mathrm{mg} / \mathrm{dl}$.

LDL Cholesterol Level:

- Optimal - <100 mg/dl;

- Above optimal - 100-129 mg/dl;

- Borderline high - 100-159 mg/dl;

- High - 160-189 mg/dl;

- Very high $-\geq 190 \mathrm{mg} / \mathrm{dl}$.

HDL Level:

- Low - <40 mg/dl;

- High $-\geq 60 \mathrm{mg} / \mathrm{dl}$.

Serum Triglycerides:

- Normal - < 150 mg/dl;

- Borderline High -

- High - 200-499 mg/dl;

- Very High - $\geq 500 \mathrm{mg} / \mathrm{dl}$.

Elevated Lipid Profile:

$>$ Serum Cholesterol - >200 mg/dl;

$>$ Serum LDL - >160 mg/dl;

$>$ Serum VLDL - >70 mg/dl;

$>$ Serum Triglycerides - >170 mg/dl;

$>$ Serum HDL - 45-70 mg/dl.

Subjective Parameters:

Chalatva of Sphik

- Absence of chalatva-0;
- Presence of chalatva -1 .

Chalatva of udara

- Absence of chalatva - 0;

- Presence of chalatva -1 .

Chalatva of sthana

- Chalatva of breasts - absent - 0;

- Chalatva of breasts-present -1 .

Alasya/Anutsaha

- Doing work satisfactorily with proper vigor in time 0 ;

- Doing work satisfactorily with late initiation - 1;

- Doing work unsatisfactorily under mental strain and taking time -2 ;

- Not beginning any work on his own obligation and doing little work - 3;

- Refuses to take the initiative and not want to function even after pressure -4 .

Krichra Vyavaya

- Unimpaired libido and sexual performance - 0;

- Decreased libido but ability to conduct sexual act - 1 ;

- Decreased libido but ability to perform sexual act with difficult - 2;

- Loss of libido and inability to perform sexual act - 3;

Daurbalya

- Can do regular exercise - 0 ;

- Can do moderate exercise without trouble - 1;

- Can only perform mild exercise - 2;

- Can do mild exercise with very difficult - 3;

- Cannot do even mild exercise - 4 .

Daurgandhya

- Absence of bad odour - 0;

- Occasional bad smell from the body that is removed after Bathing - 1;

- Persistent bad smell restricted to near places that is impossible to mask by deodorant -2 ;

- Persistent bad smell sensed from long distance that is not suppressed by deodorant -3 ;

- Persistent bad smell felt from long distance that is also intolerable to the patient himself -4 .

Svedhaabaada

- Sweating after hard work and rapid movement or in hot weather - 0;

- Profuse sweating after moderate work and movement -1 ;

- Sweating after little work and movement - 2;

- Profuse sweating after some work and movement - 3;

- Sweating even at rest or in cold weather -4 .

Kshudatimaatram

- Normal hunger - 0;

- Excessive hunger -1 .

Pipasaatiyoga

- Normal thirst - 0;

- Excessive thirst - 1 .

\section{CASE STUdY}

On 21.1.2021, a 54-year-old non-hypertensive, nondiabetic female patient presented to the OPD with chief complaints of complete fatigue, difficulty in losing weight, 
dyspnea on exertion, abdominal obesity, flaccidity, pendulous belly, buttocks, breasts, weakness, oversleeping, lethargy, tiredness, lack of sexual desire, foul body odour, profuse sweating, polyphagia, excessive thirst for last one year. Her weight has started to rise over the last 5 years, and she is presently at the highest weight she has ever been. Patient notes that any time observe clear diet and cut back on eating. The patient complains that the pain in her legs makes every exercise impossible. The patient's initial history showed that he had experienced sudden fatigue and general debility and had been receiving home medication for three months. Cholesterol, Triglycerides, and other parameters were shown to be elevated in the lipid profile. On assessment, the patient was afebrile, awake, and well-oriented, listening to verbal orders while experiencing fatigue when walking and standing for long periods of time.

- Time of Onset: Adult, last 1 year;

- Type of Onset: Gradual;

- Course: Progressive;

- Aggravating Factors: Eating \& Sedentary habit.

Past History - Non contributory

Personal History:

- Ahara: Samisha;

- Dietary Habits: Visamasana;

- Dominant Rasa: Madhura;

- Kostha: Madhyama;

- Bowel (Stool): Irregular, mild constipation;

- Consistency: Hard;

- Micturation: Scanty;

- Frequency: 4-5 times/24 h;

- Snana: Daily \& Regular;

- Exercise: Irregular \& Occasional;

- Physical Activity: Household work

- Type of work: Sitting \& Sedentary ph;ysical work;

- Hours of work: 2-3 hours/day;

- Supplementary Diets: Tea;

- Sleep: Disturbed Day 1-2/hrs. Night 6/h;

- Swapna: Yes;

- Addiction: Tranquilizers \& Others - syrup Corex;

- Perspiration: Bahula;

- Emotional Makeup: Tension.

Menstrual history - Age of menarche 14 year - M. C. 3-4 days, Irregular, Menopause at 49 years.

Obstetric history - Multipara, Drug induced abortion twice. Previous history of taking birth control pills.

General examination:

- Height: $158 \mathrm{~cm}$;

- Weight: $88 \mathrm{~kg}$;

- BP: $130 / 90 \mathrm{~mm} / \mathrm{Hg}$;

- Pulse: 92 /min;

- Temperature: 99.10F;

- Respiratory rate: $24 / \mathrm{min}$.

Treatment Schedule:

1. Medoharvidangadi Loha (Guggulu, Sunthi, Marich, Pippali, Mustak, Chitrakmula, Haritaki, Bhibhitaki, Amalaki, Vidang, Bilwa, Shweta Chandan, Sugandhabala, Patha, Ushir, Balamula, Loha Bhasma) (125 mg each tablet) $1 \mathrm{BD}$ for 1 month.
2. Amritadi Guggulu (Guduchi, Choti Ela, Vidanga, Indrayava, Haritaki, Bhibhitaki, Amalaki, Guggulu) (250 mg of each tablet) 2 BD with luke warm water for 1 month.

3. Bilvadi Kwath (Bilwa, Vasa, Kashmiri, Patala) $20 \mathrm{ml}$ BD for 1 month.

\section{RESULT}

TABLE I: FUNCTIONAL ASSESSMENT

\begin{tabular}{ccc}
\multicolumn{3}{c}{ TABLE I: FUNCTIONAL ASSESSMENT } \\
\hline Parameter & Before Treatment & After Treatment \\
\hline Height & $158 \mathrm{~cm}$ & $158 \mathrm{~cm}$ \\
Weight & $88 \mathrm{Kgs}$ & $85 \mathrm{Kgs}$ \\
BMI & $35.3 \mathrm{Kg} / \mathrm{m}^{2}$ & $34 \mathrm{Kg} / \mathrm{m}^{2}$ \\
\hline
\end{tabular}

TABLE II: PATHOLOGICAL INVESTIGATION

\begin{tabular}{ccc}
\hline \multicolumn{3}{c}{ TABLE II: PATHOLOGICAL INVESTIGATION } \\
\hline Lipid Profile & Before Treatment & After Treatment \\
\hline Serum Cholesterol & $248 \mathrm{mg} / \mathrm{dl}$ & $212 \mathrm{mg} / \mathrm{dl}$ \\
Serum LDL & $178 \mathrm{mg} / \mathrm{dl}$ & $146 \mathrm{mg} / \mathrm{dl}$ \\
Serum VLDL & $184 \mathrm{mg} / \mathrm{dl}$ & $144 \mathrm{mg} / \mathrm{dl}$ \\
Serum HDL & $72 \mathrm{mg} / \mathrm{dl}$ & $57 \mathrm{mg} / \mathrm{dl}$ \\
& $49 \mathrm{mg} / \mathrm{dl}$ & $52 \mathrm{mg} / \mathrm{dl}$ \\
\hline
\end{tabular}

\begin{tabular}{ccc}
\multicolumn{3}{c}{ TABLE III: SUBJECTIVE PARAMETER } \\
\hline Parameter & Before Treatment & After Treatment \\
\hline Chala Sphik & 1 & 1 \\
Chala Udara & 1 & 1 \\
Chala Sthana & 1 & 1 \\
Anutsaha & 3 & 1 \\
Krichra vyavaaya & 2 & 2 \\
Dourbalya & 3 & 2 \\
Dourgandhya & 3 & 1 \\
Swedhabaada & 3 & 2 \\
Kshudhatimatra & 1 & 0 \\
Pipasatiyoga & 1 & 0 \\
\hline
\end{tabular}

\section{DISCUSSION}

Hyperlipidemia is a condition of lipoprotein synthesis that can result in excess or lack of lipoproteins. Hyperipidemia can be characterised by elevated total cholesterol, LDL cholesterol, and triglyceride levels, as well as a reduction throughout HDL cholesterol levels in the blood. It is relatively discreet in terms of what the patient can detect on his or her own, making it a silent murderer. Hyperlipidemia is characterized as an elevated amount of lipids and lipoproteins in the blood, which can be linked to an increase in Medas in the body and is linked to Medo Roga in Ayurveda.

The result obtained regarding the parameter of lipid profile showed marked improvement. The difference in total serum cholesterol is $36 \mathrm{mg} / \mathrm{dl}$, serum triglycerides is $32 \mathrm{mg} / \mathrm{dl}$, serum LDL is $40 \mathrm{mg} / \mathrm{dl}$, serum VLDL is $15 \mathrm{mg} / \mathrm{dl}$ and serum HDL is $-3 \mathrm{mg} / \mathrm{dl}$. For an Ayurvedic drug to act on elevated lipid levels it should have the following effects:

It should perform Amapachana and Shodhana at the Rasa Dhatu stage, since Rasa is the primary nutritive pool from which Rakta, Mamsa, Meda, and other Dhatus obtain nutrients.

- After traversing the Rasadi Dhatus, it can cross the stage of Medo Dhatu.

- It should correct the pathology that has resulted in an excess of Medo Dhatu by encouraging the Jatharagni.

- It should do Lekhana and Upshoshana of the excess Kapha, Mamsa, Meda, Vasa, Kleda, and Sweda. 
As seen from the Ayurvedic prism, hyperlipidemia Since bahu abaddha medas circulates in the body, it can be taken as Medo roga or Medo dosha. Medo vilayana may be caused by Tikta katu, Kashaya rasa, and ushna Virya.

Medoharvidangadi Loha and Amritadi Guggulu are rooksha, teekshna, and ushna in nature, which allows them to penetrate deeper channels and remove sanga or obstruction. In nature, these medications are also ushna. In the case of hyperlipidemia, the obstruction can be seen as atherosclerosis, which is caused by fat accumulation in the arteries. As a result of the above properties, it aids in the liquefaction of these fatty blockages. The majority of drugs include tikta-katu rasa along with laghu, rooksha, and tikshana guna, which aids in Sneha-Meda-Kleda soshana. Both medicines have a KatuVipaka essence, which allows them to penetrate deeper channels and correct the Medodhatu. The Sneha-Meda-Kleda soshana is performed by Katu Rasa and Katu Vipaka. Chitraka is rich in lekhana, which aids in sroto sodhana and kapha medo vilayana. All drugs have medohara properties, and the rest of drugs have lekhana, rooksha, and teekshna properties. Deepana Pachana quality Ushna Veerya and Katu Rasa aid in the enhancement of agni, which results in Amapachana and the reduction of kleda in the body (kledasoshana). Plaque forming can be avoided in this manner. Medodhatwagni's work is restored, and the sookshma and stoola kitta bhavas are properly created. Deepana medicines are used to isolate the dhatuleena doshas from the dhatus. The undigested portions are digested by pachana medications. These medicines include teekshna guna as well as lekhana. Property is essential in Kaphamedo vikaras lekhana for relieving srotorodha. Deepana, pachana, and rochana gunas modulate metabolism at the dhatu stage, as do agni deepana, amapachana, srodho shodana, and snehakleda-medo vishoshana.

\section{CONCLUSION}

The current case study demonstrates the role of Ayurvedic therapy in the treatment of hyperlipidemia. In Ayurvedic literature, hyperlipidemia is explained in bits and pieces under the general umbrella of Sthaulya-Medoroga. Food, according to Ayurveda, is one of the primary causes of all diseases. This is mostly attributed to Mandagni's effect on inappropriate food digestion. Laghu, Rooksha gunas, Thikta Rasa, KatuVipaka, Deepana, Paachana, Kaphapittha Shamaka, Raktha-shodhaka, Hridya, and Lekhana would be perfect for controlling lipid levels in the bloodstream. The results obtained for the lipid profile parameter demonstrated a significant change. While this case study was conducted with a single patient over a short period of time, the mass study with a broad statistical approach is necessary for further evaluation.
[3] Astanga Hridaya with the commentaries, Sarvangasundara of Arundatta and Ayurveda Rasayana of Hemadri, edited by Pandit Hari Sadasiva Sastri Paradakara Bhisagacarya; Chaukhamba Orientalia, Varanasi, Ninth Edition, 2002.

[4] Ayurveda Vidwan Prof. Murthy Srikanta KR, Sharangadhara Samhita, Third Edition-1997, with English Commentary, Bangalore, Chaukhambha Orientalia.

[5] Bhaishajya Ratnavali, Govinda Das with Vidyotini Hindi commentary by Ambikadatta Shastri, editor Rajeshwar Datta Shastri, Chaukhambha Sanskrit Sansthana, 1987.

[6] Bhavamishra. Bhava Prakasha with English Translation by Prof K.R.Srikanta Murthy, 3rd edition, Varanasi, Choukhamba Krishna Das Academy, 2005.

[7] Bhela Samhita, Sutrasthana, with English Translation by Krishnamurthy K.H., Varanasi; Chaukhambha Vishwabharati. Reprint 2006.

[8] Chait A, Brunzell JD (June 1990). "Acquired hyperlipidemia (secondary dyslipoproteinemias)". Endocrinol. Metab. Clin. North Am. 19 (2): 259-278.

[9] Chakrapanidatta. Chakradatta with vaidhya prabha Hindi commentary by Dr Indradev Tripathi, edited by Prof Ramanath Dwivedi, 1st edition Varanasi, Chaukhamba Sanskrit Sansthan, 1992.

[10] Davidson's Principal's and practice of medicine, 19th edition page 308

[11] E.C.Warner: Savill's System of Clinical Medicine, 14th edition, CBS Publications, 1998.

[12] Frederickson DS, Lee RS. A system for phenotyping hyperlipidemia. Circulation 1965;31:321-7.

[13] Harsh Mohan, Text Book of Pathology, 15 th chapter, $6^{\text {th }}$ edition, Jaypee Brothers Medical Publishers(P)Ltd. New Delhi, 2010.

[14] Harita Samhita: Hariharprasada Tripathi Chaukhambha Sanskrit Sansthana, 2005.

[15] Harrisons's principles of internal medicineVol-2.; McGraw Hill book company 11th edition 1987.

[16] Madhavakara. Madhava Nidanam with Madhu Kosha Sanskrit commentary by Shri. Vijayarakshita and Shrikanta Datta, with the Vidyotini Hindi commentary, edited by Yadunandana Upadhaya, Varanasi, Chaukhambha Sanskrit Sansthan, Part II, reprint 2003.

[17] Sahastra Yogam, Hindi translation by Dr Ramnivas Sharma and Dr Surendra Sharma, 3rd edition, Varanasi: Chaukambha Vidhya Bhavan, 2002.

[18] Sharangadhara Samhita with Adhamalla's Deepika and Kashiram's Gudartha Deepika commentary, Varanasi, Krishnadas Academy, reprint 2000.

[19] Sushruta Samhita, the Nibandha Sangraha commentary by Dalhanacharya and the Nyayachandrika Panjika of Sri. Gayadasacharya on Nidana Sthana, edited by Vaidya Jadavji Trikamji Acharya and Narayanarama Acharya, Kavyatirtha, Chaukambha Surabharati, Varanasi; reprint 2003.

[20] The Ayurvedic Formulary of India. Part I, Ministry of Health \& Family Welfare, New Delhi: Government of India, 2nd edition, 2003.

[21] Vangasena.Vangasena Samhita - with Hindi commentary from Dr Rajiv Kumara Roy, edited by Dr. Rajiv Kumara Roy, 1st edition, Varanasi: Prachya Prakashan; 2000.

[22] Yogaratnakar. With Vaidhya Prabha Hindi commentary, by Dr. Indradev Tripathi and Dr. Dayashankar Tripathi, Varanasi, Krishna Das Academy, 1st edition 1998.

Dr. Jaya Saklani Kala is Associate Professor at the department of Kayachikitsa (Ayurveda Medicine), Rishikul Campus, Haridwar, Uttarakhand, India. Pursued graduation and postgraduation MD, from Lucknow University, Uttar Pradesh. Now presently doing $\mathrm{PhD}$ (Ayurveda Medicine) from Uttarakhand University, Dehradun, Uttarakhand, India. Research topic for post-graduation was Anidra (Insomnia) and presently worked on Hypertension during PhD studies. Working as Post graduate Supervisor for last 7 years, and more than 20 MD students were supervised as Supervisor and Co-supervisor.

\section{REFERENCES}

[1] Agnivesha. Charaka Samhita, redacted by Drudabala, with Ayurveda Deepika commentary by chakrapani Varanasi, Chaukamba Sanskrit Sansthana; reprint: 2004. Suthrasthana 28/45.

[2] Astanga Samgraha with the commentary of Indu, Published by Central Council for research in Ayurveda and Siddha (CCRAS) New Delhi 1991. 